\title{
Digestate, ash and Trichoderm based fertilizer - production line concept design
}

\author{
Marcin Jewiarz ${ }^{1, *}$, Marek Wróbel, Jarosław Frączek, Krzysztof Mudryk, Krzysztof Dziedzic \\ ${ }^{1}$ University of Agriculture in Krakow, Department of Mechanical Engineering and Agrophysics, 120 \\ Balicka st. 30-149 Kraków, Poland
}

\begin{abstract}
Paper presents design process of the prototype line, dedicated for production of fertilizer pellets from digestate-ash mixture. For enrichment of the nutritional characteristics of the final product additives were also used, like urea, elemental sulphur or phosphorite, and special fungal strains from Trichoderma spieces. During this process raw material will be dried (raw digestated), mixed, granulated and packed in one technological line. Presented concept, shows that there is possible to produce high quality fertilizer, from waste materials derrived form Green energy production, what should be one of very interesting ways to develop digestate and ash from biomass combustion.
\end{abstract}

\section{Introduction}

Production of the renewable energy, leads in many cases to waste production. The best examples of such technologies, are biomass combustion and biogas plants. In first case, there is produced ash, which could be reclaimed as valuable fertilizer. The Table 1 presents specific data of ash from biomass combustion

On the other hand, biogas plants produces large quantities of solid digestate, which in case of fermentation of agricultural residues can be also treated as valuable source of nutrients for plants. In many cases such highly watered digestate is deposed directly to land fields, but this method has some important disadvantages. First of all, usually, fresh digestate emits large amounts of odours, what limits its usage near household. What is also important, in many countries, there are limits concerning amount of digestate dropped on the field during year. The last one of the cons is profitability of the transportation of raw digestate, which in many cases is limited up to $15 \mathrm{~km}$ from the place of production [1].

Increase in energy share of biogas and biomass combustion, leads to higher amounts of this two waste-by-products, which needs to be processed in some way.

The aim of this paper is to present concept line design, capable of production of fertilizer mixture, with flexible composition. For the production will be used waste by-products form Renewable Energy production (ash form biomass combustion and solid digestate) with supplementation of sulphur, urea and phosphorite. What is also important to enhance

\footnotetext{
*Corresponding author: marcin.jewiarz@urk.edu.pl
} 
assimilability of the nitrogen to the plants, part of digestate will be inculcated with special strains of Trichoderma $[2,3]$.

Table 1. Ash composition form biomass combustion [4].

\begin{tabular}{|c|c|}
\hline Parameter & Value range \\
\hline Moisture $(\%)$ & $0.6-3.3$ \\
\hline $\mathrm{TC}(\%)$ & $1.4-12.3$ \\
\hline $\mathrm{Cl}^{-}(\mathrm{g} / \mathrm{kg}, \mathrm{DM})$ & $6.2-254.2$ \\
\hline $\mathrm{NO}^{-}(\mathrm{g} / \mathrm{kg}, \mathrm{DM})$ & $0-2.2$ \\
\hline $\mathrm{PO}^{3-}(\mathrm{g} / \mathrm{kg}, \mathrm{DM})$ & $13.4-39.5$ \\
\hline $\mathrm{Na}(\mathrm{g} / \mathrm{kg}, \mathrm{DM})$ & $3.3-47$ \\
\hline $\mathrm{K}(\mathrm{g} / \mathrm{kg}, \mathrm{DM})$ & $47.2-570$ \\
\hline $\mathrm{Mg}(\mathrm{g} / \mathrm{kg}, \mathrm{DM})$ & $0.4-30$ \\
\hline $\mathrm{Ca}(\mathrm{g} / \mathrm{kg}, \mathrm{DM})$ & $5.4-316$ \\
\hline $\mathrm{Al}(\mathrm{g} / \mathrm{kg}, \mathrm{DM})$ & $0.01-19.1$ \\
\hline $\mathrm{Fe}(\mathrm{g} / \mathrm{kg}, \mathrm{DM})$ & $0.7-13.2$ \\
\hline
\end{tabular}

Increase in energy share of biogas and biomass combustion, leads to higher amounts of this two waste-by-products, which needs to be processed in some way [5].

\section{Design Methodology}

The design process was based on selection of unit operation best equipment by means of Scoring Design Method and derived from it [6-8]. Concept provides analysis of each unit operation by means of several key factors, selected at the first stage of design. What is important, each factor is described by importance multiplier, usually in rage from 0 to 1 . Then selection of each apparatus is made by means of scoring each of key factors (scale 0 20 points). Sum key factors score multiplied by importance coefficient, is used to rank devices (apparatus with the highest score are selected), and based on the highest score in each unit operation groups

\subsection{Installation requirements}

Based on experience from earlier research during project, which were aimed on assessment of physical properties of the materials used in production of this fertilizer mixture, several key boundaries conditions for design process were stated.

- For stationary production, the facility should be able to work in continuous regime, to assure high profitability of final product.

- The installation capacity should be higher than $1 \mathrm{Mg} / \mathrm{h}$ to provide profitable production

- As a feedstock for production will be used dewatered digestate, with moisture content below $75 \%$, will be stored in bulk under shelter or roofed site

- The transport of the digestate to the infeed hopper of the dryer will be realised by multifunctional wheel loader, used also for other transportation procedures during production.

- The hopper should have capacity which will be sufficient for $1 \mathrm{~h}$ of production (approx. $2 \mathrm{Mg}$ of digestate).

- The drying of the digestate, will be realized by means of drum or belt dryer. 
- Additives: ash, elemental sulphur, urea and phosphorite will be delivered by tankers to silos located in the factory, the capacity of silos should be enough for $24 \mathrm{~h}$ of continuous production.

- Based on the research made in previous parts of the Grant, the digestate and ash mixture should be stabilised up to 3 hour before granulation

- The composition of the fertilizer, should be flexible, as it will be set according to the current needs of market.

- The installation should be capable of production two types of pellets - form mixture digestate, ash and additives, and form digestate incubated with Trichoderma, as this fungi will not survive in the mixture with ash (to high $\mathrm{pH}$ level).

- The final mixture of pellets with and without ash should be prepared just before confection process.

\subsection{Raw material description}

Production of this type of fertilizer requires mixing of several raw materials of mineral and organic origin. That's why it was important during first stages of project to determine key quality parameters of this materials. The physical analysis of the raw materials used in pellet production are provided in Table 2 .

Table 2. Basic analysis of physical quantities of ash and digestate.

\begin{tabular}{|c|c|c|}
\hline Quantity & Digestate & Ash \\
\hline Moisture $(\%)$ & $73-75$ & $1-3 \%$ \\
\hline Bulk density $\left(\mathrm{kg} / \mathrm{m}^{3}, \mathrm{FM}\right)$ & $475-500$ & $570-580$ \\
\hline Specific density $\left(\mathrm{kg} / \mathrm{m}^{3}, \mathrm{DM}\right)$ & $220-233$ & - \\
\hline Absolute density $\left(\mathrm{g} / \mathrm{cm}^{3}, \mathrm{DM}\right)$ & $1.85-1.91$ & $2.46-2.48$ \\
\hline Absolute porosity $(\%, \mathrm{DM})$ & $92 \%$ & 76 \\
\hline Angle of repose $\left({ }^{\circ}, \mathrm{DM}\right)$ & $47-56$ & $52-60$ \\
\hline
\end{tabular}

\section{Design presentation}

Results of the design process were placed in the warehouse with dimensions $46 \times 19 \mathrm{~m}$ and $7 \mathrm{~m}$ high (no 25 on Figure 1). Precise visualisation is presented of Figure 1. The nominal capacity of the whole line was set in the range $1.5-1.7 \mathrm{Mg} / \mathrm{h}$ (depends upon composition of the fertilizer mixture). 


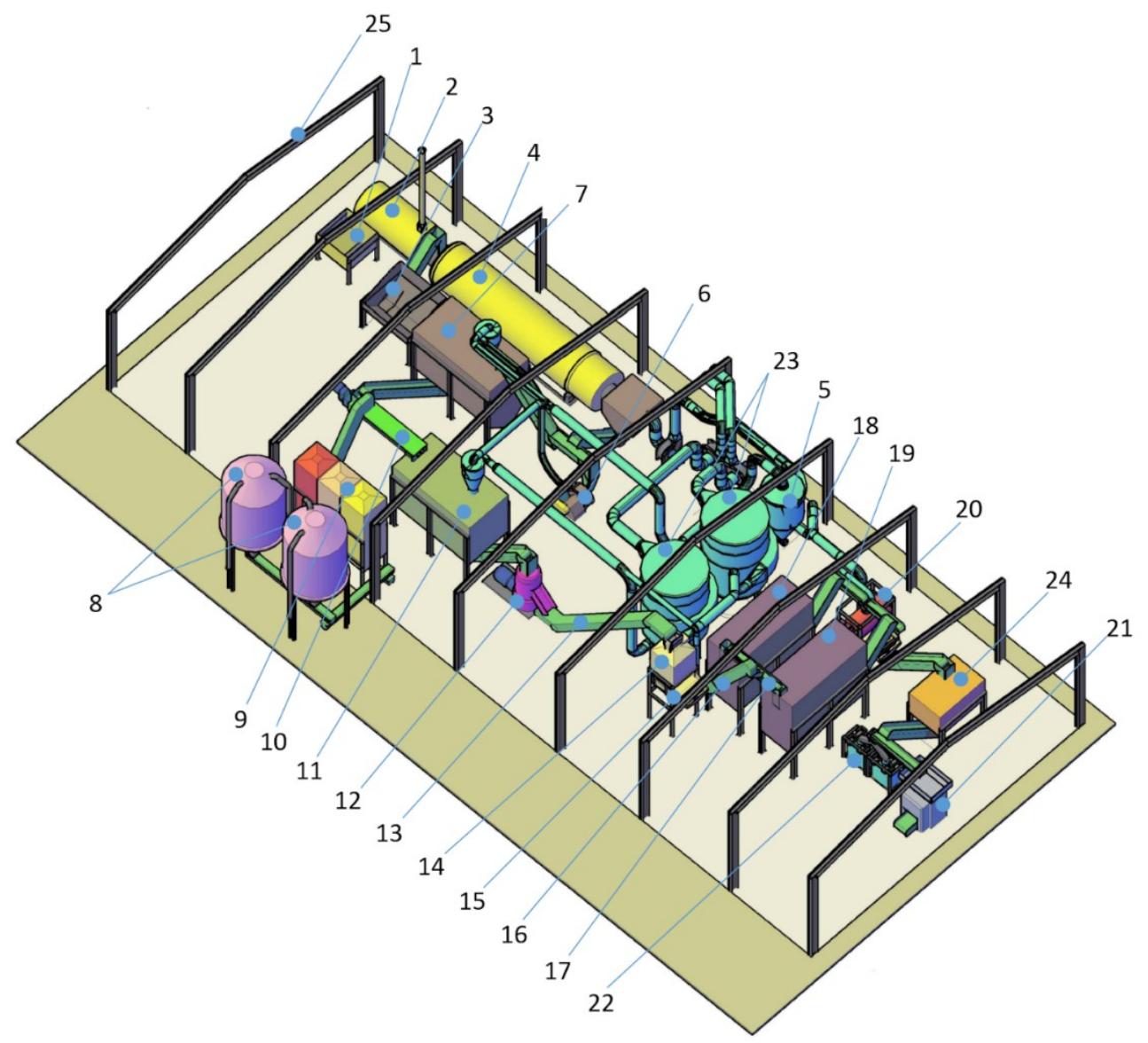

Fig. 1. Complete digestate-ash to fertilizer line (description of numbers in text).

\subsection{Preparation of raw materials}

\subsubsection{Drying of digestate}

Granulation of the organic materials, requires specified condition, one of them is moisture content of raw materials, which usually should be in the range $20-25 \%$ to obtain satisfy quality product. As moisture content of the digestate could vary (even if it was initially dewatered), so there is need to take out the water excess by means of drying. In this case best solution (according to score method) is classic direct contact drum dryer (no 4). As source of drying agent (flue gases) biomass burner was selected (no 2) with $4.5 \mathrm{~m}^{3}$ fuel tank (no 1). What is important, biomass combustion heater has a main advantage, as the ash produced during combustion, can be utilize on site, as feedstock for fertilizer production.

The heat output of the burner was estimated on approx. 1.5 MWth, and should be able to dry up to $2 \mathrm{Mg}$ of digestate form moisture content $70 \%$ to $30 \%$. Higher than range $20-$ $25 \%$ humidity of the raw material is connected with mixing it before granulation with ash (dry material). As the hopper for the raw digestate (no 3) should be able to supply line for 1 hour of raw material, the volume to it should be approx. $6 \mathrm{~m}^{3}$. The fresh material will be supply to hopper by means of multifunctional loader. If the structure of the digestate requires fragmentation, the installation is equipped with hammer mill (no 6). When the digestate is 
free of big or fibrous particles, material after drying is transported directly to mixing stage. In other case movement of reversible belt conveyer transports the digestate to milling stage.

\subsubsection{Storage of raw materials}

The storage of the raw material is divided to two stages. In first are stored digestate, and digestate inoculated with Trichoderm. Both this processes are realized in roofed shelter, in case of Trichoderm there will be also polymer covers, to maintain best conditions for fungi. Both storage places should be equipped with waste effluent collection system, connected to waste water treatment facility. The second part of the raw material storage system, will be additives section: ash, sulphur, urea, phosphorite silos (no 8 and 9). For ash, as it share in the final product will be the highest thru all additives (up to $75 \%$ ), the total capacity of the ash silos were estimated on $67 \mathrm{~m}^{3}$, what should suffice for daily production of the most ash consuming mixture. The rest of the additives will be stored in $12 \mathrm{~m}^{3}$ tanks. Supply of the materials will be realised by means of pneumatic transport form the tankers.

\subsubsection{Raw material mixing}

Preparation of accurate mixture is one of the key operations to achieve repeatable quality of the fertilizer. Continuous production requires high capacity of mixers, to supply production process. For this raw materials, best method seems to be double shaft mixer (no 10) with capacity up to $6 \mathrm{~m}^{3} / \mathrm{h}$, mainly due to flexibility in raw material composition. After this operation mixture is transported to stabilization tank (no 11), with capacity $40 \mathrm{~m}^{3}$. Recommended stabilization period is $3 \mathrm{~h}$.

\subsection{Granulation and confection}

Production of granules will made by means of flat die pellet press (no 12), with output capacity up to $2 \mathrm{Mg} / \mathrm{h}$. What is important, characteristics of the materials requires special geometry of the die channels. After granulation fertilizer pellets are transported by belt conveyers (no 13) to cooler (no 14), and next there is separation (no 15), crushed pellets and loose parts are recycled and high quality granules are transported to selected storage container by reversible conveyer (no17). To first goes granules with digestate, ash and supplements (no 18), to second digestate with Trichoderm (no 19).

\subsection{Mixture preparation and confection}

Final mixture is prepared in batch type single shaft mixer (no 20), with precise dosing cells. After mixing (no 24), product is packed by means of fully automated bagging machine (no 21), or packed to the Big-Bags (no 22).

\subsection{Process gas cleaning}

The production of pellets usually is connected with production of high amount of dust, which should be recycled to the installation. To omit emission of fine particles to air, mostly all devices (when it is possible) works in the slight vacuum, and all air channels are connected to the dedusting system. For rough cleaning of air, cyclones (no 5) were used, with recycle of particles form dust hopper. At the end of installation, there is section of bag filters and fans (no 23), which are capable to separate smallest particles. From this stage, dust is also recycled to the process line. 


\section{Summary}

The presented in the paper concept of the stationary production line for production of multicomponent fertilizer, form ash, digestate, and other components, is a very complex system, involving several aspects presented in the assumption. The flexibility of the installation, gives opportunity to process materials with different materials with unstable properties (moisture, morphology, densities). The design is focused on near to zero waste production, as ash from drying air heater can be used directly to fertilizer production, and all dust separated form air stream is recycled to the granulation process. The innovation during production, is addition a Trichoderm fungi to digestate, what should increase nitrogen assimilability for the plants.

Research was funded by the National Centre for Research and Development and the National Fund for Environment Protection as a part of GEKON program - project no. GEKON1/05/214543/38/2015 "Proecology production of organic and mineral fertilizers based on waste: by-porducts of combusiton and biogasification of biomass".

\section{References}

1. J. Dahlin, M. Nelles, C. Herbes, Res., Cons. and Rec., 118, 27-38 (2017)

2. M.B. Rubio, R. Hermosa, R. Vicente, F.A. Gómez-Acosta, R. Morcuende, E. Monte, W. Bettiol, Front. In. Plant Sci., 8, article 294 (2017)

3. A. Pertiwinin, E.C. Budyanto, M. Hidayat, R.Y. Soeherman, M.F. Habibi, Jou of Biol. Sci., 17, 21-27 (2016)

4. C. Lanzerstorfer, Jou. of Env. Sci., 30, 191-197 (2015)

5. J. Lindner, S. Zielonka, H. Oechsner, A. Lemmer, Bio. Tech., 178, 194-200 (2015)

6. A. Jahan, K.L. Edwards, M. Bahraminasab, Multi-criteria Decision Analysis for Supporting the Selection of Engineering Materials in Product Design, (ButterworthHeinemann, 2016)

7. J.W. Creswell, Qualitative Inquiry and Research Design: Choosing Among Five Approaches, (SAGE Publications, Inc, 2012)

8. J.R. Moore, N.R. Baker, IEEE Trans. on Eng. Man., 16, 90-98 (1969) 